\title{
Binding International Norms, Jus Cogens
}

\section{Erjona Ramaj}

UET, Albania

\section{Abstract}

Article 53 of the Vienna Convention of 1969 states that a treaty is considered invalid if it is in conflict with existing norms of jus cogens, and under Article 64 of the treaty becomes invalid if it conflicts with a norm youngest of the same nature. The case Nicaragua against the United States made clear that the notion of jus cogens is steadily entrenched in international law, however, is still necessary to determine accurately that power rates referred to in Articles 53 and 64 of the Vienna Convention. Jus cogens norms include more those norms relating to morality or natural law than with traditional positivist rates derived from State practice. In general, this includes making aggressive war, crimes against humanity, war crimes, sea piracy, genocide, apartheid, slavery, and torture.Jus cogens norms are norms of customary international law which are so important, it can not be changed through treaties. Under the Vienna Convention on the Law of Treaties, any treaty that is contrary to jus cogens norms is invalid. Jus cogens norms are not listed, there is no catalog, their determined by any authoritative body, but these rates come from judicial practices and political and social attitudes, which are not values static. Jus cogens norm of unconditional right international, accepted and recognized by the international community norm from which no deviation is permitted. Unlike the common law, which traditionally requires the consent and

It lets change obligations between states through treaties, norms jus cogens can not be violated by any state "through treaties international or local regulations or special customary, or even through general rules of customary not have the same normative force.

Keywords: jus cogens, binding international norms, Vienna Convention, customary international law, international treaties 